\title{
MAX WEBER ON POLITICS, REASON, AND THE CLASH OF VALUES AND APPROACHES TO ETHICS
}

\author{
Manuel Knoll \\ Istanbul Şehir University \\ manuelknoll@sehir.edu.tr \\ orcid: 0000-0002-0651-1915
}

\section{ABSTRACT}

This article investigates how Max Weber's theory of value conflict is connected to his realist understanding of politics and how he conceives the relation of politics and ethics. This investigation also covers Weber's views on the argumentative limits of the social sciences and ethics. The center of Weber's philosophy of science is constituted by his methodological thoughts on "ethical neutrality" (Wertfreiheit) of the social sciences. The first thesis of this paper contends that Weber's theory of a clash of irreconcilable values and ideals goes back to Nietzsche. According to the second thesis of the article, the general claim of Weber's philosophy of science is that there is no possibility of an ultimate rational, philosophical, or scientific grounding of values and normative theories. Weber's endorsement of an ethics of responsibility in the field of politics led to the criticism that he contradicts his postulate of the "ethical neutrality" (Wertfreiheit) of the scientist. The third thesis of the paper claims that Weber's arguments for a political ethics of responsibility are compatible with his methodological postulate. 


\section{MAX WEBER'S UNDERSTANDING OF POLITICS AND THE STRUGGLE OF OPPOSING VALUES}

About 100 years ago, during the summer of 1919, Max Weber published a talk he had given in Munich during the preceding revolutionary winter that followed the end of World War I. ${ }^{1}$ The talk was titled "Politik als Beruf." To render the two meanings of the German "Beruf," his title was translated as "The Profession and Vocation of Politics." ${ }^{2}$ Weber is maybe best known as one of the founders of sociology and for his (economic) sociology of religion. However, he was also philosopher, historian, political economist, and jurist. And his talk on politics in Munich was not an "occasional job," but was based on a considerable number of political writings, which he mostly penned during World War I. ${ }^{3}$

Max Weber's understanding of politics follows the realist tradition that goes back to Thucydides and some of the Greek sophists. ${ }^{4}$ One feature of this tradition, to which also Niccolò Machiavelli belongs, is a sober and realistic view of political reality, human

1 In 1917, Weber was an invited speaker in a lecture series, organized by a student association called "Münchner Freistudentischer Bund." Before his talk on politics, he had given in the same series a talk on "The Profession and Vocation of Science" (Wissenschaft als Beruf).

2 Max Weber, "The Profession and Vocation of Politics," Weber. Political Writings, ed. Peter Lassmann and Ronald Speirs (Cambridge: Cambridge University Press, 1994), 309-69. In the previous rendering by H. H. Gerth and C. Wright Mills, this title was translated as "Politics as a Vocation." Similarly, Gerth and Mills translated Weber's earlier talk as "Science as a Vocation"; both in From Max Weber. Essays in Sociology. Trans. and ed. H. H. Gerth, and C. Wright Mills (Oxford: Oxford University Press, 1946), 77-156. Both traditional renderings do not do justice to the fact that the German "Beruf" means both "vocation" and "profession."

3 Most of these writing are translated into English and published in the 400 page volume Weber. Political Writings. The German edition of his political writings contains 600 pages; Max Weber, Gesammelte Politische Schriften, ed. Johannes Winckelmann (Tübingen: J. C. B. Mohr / Siebeck, 1988). For the historical background of Weber's talk see Kari Palonen, Eine Lobrede für Politik. Ein Kommentar zu Max Webers "Politik als Beruf" (Opladen: Leske and Buderich, 2002), 112.

4 In the volume Roots of Realism, which is devoted to different aspects of realism in international politics, three articles are devoted to Thucydides and one to the sophists; The Roots of Realism, ed. Benjamin Frankel (London: Routledge, 1996). 
being, and its moral defects. ${ }^{5}$ It rejects "ideal theory" and considers only pure factuality. According to political realism, power is the central category both in politics and for an understanding of the "political." ${ }^{\prime}$ For Weber, politics means "striving for a share of power or for influence on the distribution of power, whether it be between states or between the groups of people contained within a single state." ${ }^{7}$ He states that "all politics is essentially struggle." According to Weber, the political struggle is part of a bigger and more fundamental fight. This is the constant struggle of opposing values and ideals. As early as 1904, Weber states that one "must recognize" that "the highest ideals, which move us most forcefully, are always effective only in the struggle with other ideals which are just as sacred to others as ours are to us." ${ }^{9}$ In 1917, he puts his theory of value conflict even more dramatically, "It is really a question not only of alternatives between values but of an irreconcilable death-struggle, like that between 'God' and the 'Devil'. Between these, neither relativization nor compromise is possible. At least not in the tru e sense [dem S in n nach nicht $].{ }^{10}$ One main aim of

5 Weber, "The Profession and Vocation of Politics," 360. According to a contemporary political science textbook, Machiavelli and Weber are the main representatives of a realist conception of politics; Dirk Berg-Schlosser and Theo Stammen, Einführung in die Politikwissenschaft (Munich: Beck, 1995), 25-26.

6 Cf. Berg-Schlosser and Stammen, Einführung in die Politikwissenschaft, 25-26.

7 Weber, "The Profession and Vocation of Politics," 310. After reviewing the publications of historians, political scientists, and sociologists on Weber's reflections on politics, Hans Henrik Bruun states that their "results have been roughly the same: conflict and power are, in Weber's view, the fundamental conditions of political activity"; Hans Henrik Bruun, Science, Values and Politics in Max Weber's Methodology, New Expanded Edition (Aldershot: Ashgate, 2007), 239.

8 Max Weber, "Parliament and Government in Germany under a New Political Order," Weber. Political Writings, 219. For the political context of Weber's time, for his nationalism and the "imperialist power-state he desired" see Stephen P. Turner, and Regis A. Factor, Max Weber and the Dispute over Reason and Value: A Study in Philosophy, Ethics, and Politics (London: Routledge, 1984), 10, 7-29.

9 Max Weber, “'Objectivity' in Social Science and Social Policy," Max Weber, The Methodology of the Social Sciences, trans. and ed. Edward Shills and Henry Finch (Illinois: The Free Press of Glencoe, 1949),57; trans. slightly changed by M.K.

10Max Weber, "The Meaning of 'Ethical Neutrality' in Sociology and Economics," Weber, The Methodology of the Social Sciences, 7-18. Emphasis * 
politics is, for Weber, to fight out this struggle of antinomic values and ideals.

Weber holds the pluralism and struggle of opposing values to be a characteristic feature of modernity. This struggle was halted in Europe for centuries through the unchallenged prevalence of Christianity, which brought about cultural unity. However, after the demise of the Christian world view, it broke out again. ${ }^{11}$ For Weber, it is a "fundamental fact" that modern man "is destined to live in a godless and prophetless time." 12 This diagnosis is a reformulation of Nietzsche's famous statement "God is dead," which means "that the belief in the Christian God has become unbelievable." ${ }^{13}$ Weber accepts Nietzsche's diagnosis, but not his "prophecy" of the "Übermensch." Nevertheless, the first thesis of this article claims that Weber's theory of a clash of irreconcilable values goes back to Nietzsche. Although the Kantian or neo-Kantian influence on Weber's methodology cannot be denied, it is often overstated in the literature, which frequently neglects Nietzsche's importance for his thought. ${ }^{14}$

through letter-spacing by Weber in the German original. All German words in the translations of Weber's writings are inserted by M.K. In his article, Kenneth Westphal argues that, strictly speaking, "values do not clash," but only people who pursue what they value; Kenneth R. Westphal, "Cosmopolitanism without Commensurability: Why Incommensurable Values are Worthless," Jahrbuch für Recht und Ethik 27 (2019): 243-44. However, neither Nietzsche nor Weber make such subtle distinctions.

11 Max Weber, "Science as Vocation," From Max Weber. Essays in Sociology, 148-49.

12 Weber, "Science as Vocation," 153.

13Friedrich Nietzsche, The Gay Science, trans. J. Nauckhoff (Cambridge: Cambridge University Press, 2001), III 125, V 343; 119-20, 199.

14 Weber does refer several times to Heinrich Rickert and his term "value relation" (Wertbeziehung); Weber, "'Objectivity' in Social Science and Social Policy," 76-77, 81; and Weber, "The Meaning of 'Ethical Neutrality'," 21-22; cf. Bruun, Science, Values and Politics, 20-21. Interpreters who claim a strong Kantian or neo-Kantian influence on Weber are Agathe Bienfait, Freiheit, Verantwortung, Solidarität. Zur Rekonstruktion des politischen Liberalismus (Frankfurt am Main: Suhrkamp, 1999), 130-71; and Wolfgang Schluchter, Religion und Lebensführung, Bd. 1: Studien zu Max Webers Kultur- und Werttheorie (Frankfurt am Main: Suhrkamp, 1988). Hans Henrik Bruun claims, "Value freedom was at the heart of the methodological views of Kant and the neo-Kantians, who provided Weber with the philosophical platform from which he was able to conduct his determined attacks on naïve historicism, emanationism, vulgar Marxism, and positivism. Properly understood, it is also the logical corollary of his central thesis of the value conflict"; Bruun, Science, Values and Politics, 11. 
Maybe the most important part of Weber's "The Profession and Vocation of Politics" is his discussion of the relation of politics and ethics. Weber refuses both the interpretation that they are unrelated and the view that one single approach to ethics is able to regulate all spheres of human conduct. ${ }^{15}$ Weber's discussion of the relation of politics and ethics is linked to his philosophy of science and in particular to his methodological thoughts on "ethical neutrality" (Wertfreiheit) ${ }^{16}$ of the social sciences. This well-known postulate means primarily that social scientists are unable to scientifically demonstrate which practical phenomena are "approvable" (billigenswert) and which ones are "objectionable" (verwerflich). ${ }^{17}$ In short, "value-judgments" (Wertungen) cannot be assessed scientifically. Social scientists should clearly distinguish the spheres of "is" and "ought," or of facts and values. ${ }^{18}$ Weber asks for a strict separation of "purely logically deducible and empirical factual assertions on the one hand, and practical, ethical or philosophical value-judgments on the other." ${ }^{19}$ He holds such strict separation not only to be possible, but to be an "imperative requirement of intellectual honesty" (intellektuelle Rechtschaffenheit) and "a specific virtue" and "duty" of the academic teacher. ${ }^{20}$

Weber's views on "ethical neutrality" (Wertfreiheit) and a clear distinction between the spheres of "is" and "ought," or of facts and norms, entails that a scientist should not commit the fallacy

15Weber, "The Profession and Vocation of Politics," 357; cf. 357-368.

16 "Ethical neutrality" is a very free and interpretative but fitting translation of what Weber means in his German title with "Wertfreiheit." In "Der Sinn der 'Wertfreiheit' der soziologischen und ökonomischen Wissenschaften,” for good reasons Weber puts "Wertfreiheit" in quotation marks. It seems that Weber chose the term "Wertfreiheit" due to a lack of a better term. Translated literally, in the title "Wertfreiheit" would mean that the social and economic sciences are "value-free," which, of course, is not the case. Already the initial scientific act of singling out a research topic implies the value-judgment that this topic is worth knowing or researching. Weber is aware of that; Weber, “'Objectivity' in Social Science and Social Policy,” 72, 76-77; Weber, “The Meaning of 'Ethical Neutrality',” 22.

17 Weber, “The Meaning of 'Ethical Neutrality'," 1.

18 Bruun points out that "Weber was certainly not the author of the theory of logical disjunction between 'Is' and 'Ought', on which the demand for value freedom is based”; Bruun, Science, Values and Politics, 12.

19 Weber, “The Meaning of 'Ethical Neutrality'," 1.

20Weber, "The Meaning of 'Ethical Neutrality'," 2-3; Weber, "Science as Vocation," 146, 155-56. 
of deriving "ought" from "is." Despite the limits of the social sciences and reason, sociology is able to empirically study normative phenomena such as values and ideals. The social sciences can, e.g. achieve a clear understanding of the relations among different "value-judgments" or values and of the means necessary to realize them through political action. Regardless of these possible achievements, neither social scientists nor philosophers are able to assess "value-judgments" scientifically as desirable or reprehensible. In this context, Weber emphasizes "the 'limits' of ethics." According to the second thesis of this article, the general claim of Weber's philosophy of science is that there is no possibility of an ultimate rational, philosophical, or scientific grounding of values and normative theories. Weber's position still poses a serious challenge to both contemporary ethical theories and normative theories of justice, which have been propagated for some decades now.

In his discussion of the relation of politics and ethics, Weber distinguishes between two kinds of "ethically oriented activity" and two corresponding approaches to ethics that are opposed to each other. Human actions can follow an "ethics of conviction" (Gesinnungsethik) or an "ethics of responsibility" (Verantwortungsethik). ${ }^{22}$ In "The Profession and Vocation of Politics," Weber argues that while an ethics of responsibility is appropriate for the sphere of politics, and ethics of conviction is not. ${ }^{23}$ Weber's endorsement of an ethics of responsibility in the field of politics led to the criticism that he contradicts his postulate of the "ethical neutrality" (Wert-

21 Weber, “The Meaning of 'Ethical Neutrality'," 15.

22 Weber, "The Profession and Vocation of Politics," 359. In this translation, "Gesinnungsethik" und "Verantwortungsethik" have been rendered with "ethic of conviction" and "ethic of responsibility." The reason for the translation of "Ethik" with "ethic" (and not with "ethics") is likely that before Weber introduces these terms he declares that the last problem he wants to discuss in his talk is the "ethos of politics as a "cause' [Sache]"; Weber, "The Profession and Vocation of Politics," 355. The meaning of the term "ethic" is closer to "ethos" than to "ethics," the term Weber actually uses. Therefore, I have changed the term "ethic" in the translations everywhere to "ethics."

23 Bruun challenges the prevailing view that "Weber saw the ethic of responsibility as the appropriate one for the politician"; Bruun, Science, Values and Politics, 49, 259. The last section of this paper defends the prevailing view and argues against Bruun's interpretation. 
freiheit) of the scientist. ${ }^{24}$ According to the third thesis of this article, Weber's arguments for a political ethics of responsibility are compatible with his methodological postulate.

\section{WEBER'S THEORY OF VALUE CONFLICT AND NIETZSCHE'S INFLUENCE}

The first thesis of this article claims that Nietzsche is the main source of Max Weber's theory of clash of irreconcilable values. Nietzsche's influence on Weber has already been noticed and debated in the literature. ${ }^{25}$ For one thing, Weber's conception of "intellectual honesty" (intellektuelle Rechtschaffenheit) as a virtue clearly goes back to Nietzsche. ${ }^{26}$ For another thing, Weber's realist understanding of politics as struggle is informed by Nietzsche's conception of the "will to power." According to Weber, it is a "self-evident

24Lothar Waas, Max Weber und die Folgen. Die Krise der Moderne und der moralisch-politische Dualismus des 20. Jahrhunderts (Frankfurt am Main / New York: Campus, 1995), 22.

25Andrea Gerner, Wissenschaft und Leben. Max Webers Antwort auf eine Frage Friedrich Nietzsches (Göttingen: Vandenhoeck \& Ruprecht, 1994); Wilhelm Hennis, “Die Spuren Nietzsches im Werk Max Webers,” ed. Wilhelm Hennis, Max Webers Fragestellung. Studien zur Biographie des Werkes (Tübingen: Mohr / Siebeck, 1987), 167-91; Detlev Peukert, Max Webers Diagnose der Moderne (Göttingen: Vandenhoeck \& Ruprecht, 1989); Christian Schwaabe, Freiheit und Vernunft in der unversöhnten Moderne. Max Webers kritischer Dezisionismus als Herausforderung des politischen Liberalismus (München: Fink, 2002); Christian Schwaabe, "Das Schicksal des Menschen im Schatten des toten Gottes. Zur Bedeutung Friedrich Nietzsches für Max Webers Diagnose der Moderne," Der Wille zur Macht und die "große Politik" - Friedrich Nietzsches Staatsverständnis, ed. Hans-Martin Schönherr-Mann (Baden Baden: Nomos, 2010), 235-57; Tamsin Shaw, “The 'Last Man' Problem: Nietzsche and Weber on Political Attitudes to Suffering," Nietzsche as Political Philosopher, eds. Manuel Knoll and Barry Stocker (Berlin/Boston: De Gruyter, 2014), 345-80. For several other references, in particular to the Anglophone literature, see Bruun, Science, Values and Politics, 40.

26 Nietzsche suggests that intellectual "honesty" (Redlichkeit) is the "virtue from which we cannot get away, we free spirits"; Friedrich Nietzsche, $B e$ yond Good and Evil, trans. W. Kaufmann (New York: Vintage Books, 1989), VII 227; 155; cf. Manuel Knoll, "Nietzsches Kritik am Willen zum Wissen und die intellektuelle Tugend der Redlichkeit," Nietzsches Wissenschaftsphilosophie. Hintergründe, Wirkungen und Aktualität, ed. Günther Abel, and Marco Brusotti, and Helmut Heit (Berlin: De Gruyter, 2012), 257-70.

Dîvân
2019/2

117 
fact that the will to power is one of the driving motives" of political leaders. ${ }^{27}$ Weber's realist understanding of politics and of the clash of irreconcilable values can be traced farther back to Machiavelli. According to Isaiah Berlin, it is a fundamental achievement of Machiavelli that he discovered that the pluralism and struggle of values is part of the "normal human situation" and that "ends equally ultimate, equally sacred" and "entire systems of value" "come into collision without possibility of rational arbitration." 28 The parallels between Weber's and Nietzsche's philosophy and, as will be explained later, between Weber's and Machiavelli's thought are no coincidence. Machiavelli was among the thinkers Nietzsche appreciated most. Nietzsche declares, "Thucydides, and perhaps Machiavelli's Principe, are most closely related to me in terms of their unconditional will not to be fooled and to see reason in reality, - not in 'reason,' and even less in 'morality'."29

In Zarathustra, Nietzsche has his protagonist make several statements of what appears to be his own view of values and their origin. In one of them Zarathustra explains,

Indeed, humans gave themselves all their good and evil. Indeed, they did not take it, they did not find it, it did not fall onto them as a voice from the heavens. Humans first placed values into things, in order to preserve themselves, - they first created meaning for things, a human meaning! That is why they call themselves 'human,' that is: the valuator [der Schätzende]. ${ }^{30}$

Nietzsche rejects the claim of the three main monotheistic religions that God gives humans their values and moral commandments. He also refuses Plato's version of "ethical realism" and "cognitivism." ${ }^{31}$ Plato holds the good to be an objective moral

27 Max Weber, "Parliament and Government in Germany under a New Political Order," 176; cf. Weber, "The Profession and Vocation of Politics," 354.

28 Isaiah Berlin, "The Originality of Machiavelli," Isaiah Berlin, Against the Current. Essays in the History of Ideas, ed. Henry Hardy (Princeton: Princeton University Press, 2013), 94; cf. 94-99.

29Friedrich Nietzsche, Twighlight of the Idols, Friedrich Nietzsche, The Antichrist, Ecce Homo, Twilight of the Idols, and other Writings, trans. J. Norman (Cambridge: Cambridge University Press, 2005), "What I Owe the Ancients 2," 225.

$2019 / 2$

30Friedrich Nietzsche, Thus Spoke Zarathustra, trans. A. del Caro; slightly changed by M.K. (Cambridge: Cambridge University Press, 2006), "Part I: On a Thousand and One Goals," 43.

31 Nietzsche, Beyond Good and Evil, 2. 
reality about which moral knowledge can be achieved. For Nietzsche, moral facts and moral knowledge do not exist: "There are no moral phenomena at all, but only a moral interpretation of phenomena." 32 There is only a pluralism of values and of conceptions of the good. All values and meanings depend on human interpretations and value-judgments. Values and moral codes are not discovered but invented by peoples according to their needs. In line with this, Weber explains, "The fate of an epoch which has eaten of the tree of knowledge is that it must know that we cannot learn the meaning of the world from the results of its analysis, be it ever so perfect, it must rather be in a position to create this meaning itself." ${ }^{33}$ According to Nietzsche, different peoples have different cultural perspectives and thus different values and moral codes that serve for their self-preservation. They are the expression of a people's "will to power" and of what they love and detest. ${ }^{34}$ Creating values and meanings is an essential characteristic of the human being as "valuator." 35 This is a remarkable "anthropological" statement because it makes the plausible claim that creating values is an essential characteristic of humans. For Nietzsche, the creation of new values usually entails the necessity of the destruction of old ones, "Change of values - that is the change of creators. Whoever must be a creator always annihilates." ${ }^{36}$ This is a first indication that Nietzsche holds clash of values to be an essential part of world history.

Nietzsche elaborates his view of struggle between opposing values in his polemical writing On the Genealogy of Morality, which Max Weber calls a "brilliant essay." ${ }^{37}$ In it Nietzsche explains,

The two opposing values "good and bad," "good and evil" have fought a terrible battle for thousands of years on earth; and although the latter has been dominant for a long time, there is still no lack of places where

32 Nietzsche, Beyond Good and Evil, IV 108; 85.

33Weber, “'Objectivity' in Social Science and Social Policy," 57.

34 Nietzsche, Thus Spoke Zarathustra, "Part II: On Self-Overcoming," 88-90.

35Cf. Friedrich Nietzsche, On the Genealogy of Morality, trans. C. Diethe (Cambridge: Cambridge University Press, 1997), II 8; 45-46.

36 Nietzsche, Thus Spoke Zarathustra, "Part I: On a Thousand and One Goals," 43; cf. Nietzsche, Thus Spoke Zarathustra, "Part II: On Self-Overcoming," 88-90.

37 Max Weber, "The Social Psychology of the World Religions," From Max Weber, 270; cf. 190.

Dîvân

$2019 / 2$ 
the battle remains undecided. You could even say that, in the meantime, it has reached ever greater heights but at the same time has become ever deeper and more intellectual: so that there is, today, perhaps no more distinguishing feature of the "higher nature," the intellectual nature, than to be divided in this sense and to be really and truly a battle ground for these opposites. The symbol of this fight, written in a script which has hitherto remained legible throughout human history, is "Rome against Judea, Judea against Rome": - up to now there has been no greater event than this battle, this question, this contradiction of mortal enemies. ${ }^{38}$

In the first essay of the Genealogy, Nietzsche offers his "hypotheses on descent" (Herkunfts-Hypothesen) regarding morality and intends to give a real "history of morality" that seems to be set against the Egyptian enslavement of Jews that presumably lasted for 400 years. ${ }^{39}$ According to Nietzsche's hypotheses, there are two opposing value-judgments, "good and bad" and "good and evil," which go back to two distinct social carriers. First is a caste of aristocratic, strong, and healthy warriors who conceive of themselves as "good" and look down at subjected peoples or their subjects as "bad." Against this "chivalric-aristocratic method" of evaluation, a caste of subdued but clever Jewish priests launches a successful and "radical revaluation of their values." 40 Driven by hatred, resentment, and the desire for intellectual revenge, Jewish priests condemn the warriors and their values as "evil" or immoral and conceive of themselves as "good" and moral. In Beyond Good and Evil, Nietzsche calls these two types of moralities "master-morality" and "slave-morality." ${ }^{11}$ Historically, the "priestly method of evaluation" of Jews, which was continued by Christian priests, led to a centuries-long prevalence of Judeo-Christian morality, which adds the ethics of Christ's "Sermon on the Mount" to the six of the ten commandments with moral content. ${ }^{42}$ Despite this historical

38 Nietzsche, On the Genealogy of Morality, I 16; trans. slightly changed by M.K., 31-32.

39 Nietzsche, On the Genealogy of Morality, 4 and 7; 6 and 8. One might also think of the period in Jewish history referred to as "Babylonian Captivity" or "Babylonian exile."

2019/2 41 Nietzsche, Beyond Good and Evil, IX: 260; 204. Nietzsche introduces these two types of morality for the first time in Human, All Too Human, I 45.

42For Weber's interpretation of "the ethics of the Sermon on the Mount" see Weber, "The Profession and Vocation of Politics," 357-59, and Weber, "Science as Vocation," 148. 
defeat of the "noble method of valuing," Nietzsche still hopes for a revitalization of "Roman" or "aristocratic values" and thus another revaluation of values. ${ }^{43}$ Such a revitalization, which he holds to be crucial for "the well being and future of the human race," had already happened briefly during the Italian Renaissance. ${ }^{44}$ And it could happen again as a consequence of the decline of Christianity since the Enlightenment period.

The influence of Nietzsche's account of a struggle of antinomic values can easily be traced in Weber's theory of value conflict. In "The Profession and Vocation of Science," Weber summarized some of his basic ideas on the "polytheism" and conflict of values. This summary is in line with related statements in his article on "ethical neutrality" (Wertfreiheit),

To "scientifically" advocate practical views is impossible - except in the case of debating the means for a fixed given aim - due to more fundamental reasons. It is meaningless in principle because the various value spheres of the world stand in irreconcilable conflict with each other. The elder Mill, whose philosophy I will not praise otherwise, was on this point right when he said: If one proceeds from pure experience, one arrives at polytheism. [...] something can be sacred not only in spite of its not being beautiful, but rather because and in so far it is not beautiful. [...] And, since Nietzsche, we realize that something can be beautiful, not only in spite of the aspect in which it is not good, but rather in that very aspect. [...] It is commonplace to observe that something may be true although it is not beautiful and not holy and not good. Indeed it may be true in precisely these aspects. But all these are only the most elementary cases of the struggle that the gods of the various orders and values are engaged in. I do not know how one might wish to decide "scientifically" the value of French and German culture; for here, too, different gods struggle with one another, now and for all times to come. ${ }^{45}$

In this quotation, Weber expresses two of his central claims about values. First, values or "value-judgments" cannot be assessed scientifically as approvable or objectionable. Weber illustrates this with the example that it is impossible to scientifically assess and

43 Nietzsche, On the Genealogy of Morality, I 16; 32.

45Weber, "Science as Vocation," 147-48. The translation of the first phrase of this quotation has been completely revised by M.K. This was also necessary because many words and a whole embedded clause were left out by the original translation. 
compare the value of the French and German culture. There exists no given or predefined "hierarchical ordering of values." ${ }^{46}$ A few phrases later he argues that any attempt to "refute scientifically" the ethic of the "Sermon on the Mount" and its request to "turn the other cheek" would be presumptuous. Second, he elucidates that radical pluralism and conflicts of values exist even on the most fundamental level. For many centuries, as previously in Plato's philosophy, in the Christian world view, different value spheres were successfully combined into a coherent unity. After the decline of Christianity in the modern world, however, this unity of the holy, the beautiful, the good, and the true breaks apart. As a consequence, the distinctions between the different value spheres and their antagonisms become again visible.

In another important passage from "The Profession and Vocation of Science," Weber explains what he holds to be the consequence of the limits of the social science, philosophy, and reason in general. As values or "value-judgments" cannot be assessed scientifically, one has no other option than to decide which ones are desirable and which ones reprehensible. This is usually called "a 'decisionist' view of the value choices one must make in life." ${ }^{47}$ Weber's friend, the legal scholar Gustav Radbruch, explicitly declared that the philosophy of law should be "decisionistic." 48 In a footnote to his article on "ethical neutrality," Weber refers to Radbruch as someone who had previously addressed "the "irreconcilability' [Unaustragbarkeit] of certain ultimate evaluations in a certain sphere of problems." ${ }^{49}$ The German term "Unaustragbarkeit," which is rendered here with "irreconcilability" (Unvereinbarkeit, Unverträglichkeit), is difficult to translate. However, it is central for an appropriate understanding of Weber's thought. Weber also uses

46Weber, "The Meaning of 'Ethical Neutrality'," 19.

47Turner, and Factor, Max Weber and the Dispute over Reason and Value: A Study in Philosophy, Ethics, and Politics, 2.

48 Gustav Radbruch, “Anglo-American Jurisprudence Through Continental Eyes,” Law Quarterly Review 208 (1936): 544.

49Weber, "The Meaning of 'Ethical Neutrality'," 10-11. Weber refers to the second edition of Radbruch's Einführung in die Rechtswissenschaft from 1913, which had been first published in 1910; Gustav Radbruch, Einführung in die Rechtswissenschaft, 2nd. edition (Leipzig: Quelle \& Meyer, 1913). Weber explains about his relation to Radbruch's views, "I diverge from him on certain problems but these are of no significance for the problem discussed here”; Weber, “The Meaning of 'Ethical Neutrality'," 11. 
this term in "The Profession and Vocation of Science" in the context of his "decisionism,"

This proposition, which I present here, always takes its point of departure from the one fundamental fact, that so long as life remains immanent and is interpreted in its own terms, it knows only of an unceasing struggle of these gods [i.e. these opposed values] with one another. Or speaking directly, the ultimately possible attitudes toward life are irreconcilable, and hence their struggle can never be brought to a final conclusion [die Unvereinbarkeit und also die Unaustragbarkeit des Kampfes]. Thus it is necessary to make a decisive choice. ${ }^{50}$

In this quotation, the noun "Unaustragbarkeit" is rendered with "can never be brought to a final conclusion." The related adjective is "unaustragbar," the associated verb "austragen." If something is "unaustragbar" in an intellectual context, it cannot be definitely and conclusively argued out. However, "Unaustragbarkeit" does not mean that one cannot argue at all. One can, of course, support views and values with reasons and arguments. As the next section will argue, in Weber's writings the term "Unaustragbarkeit" is about the impossibility of a rational "Letztbegründung," i.e., about the impossibility of an ultimate rational grounding.

\section{THE ARGUMENTATIVE LIMITS OF THE SOCIAL SCIENCES AND ETHICS}

According to the second thesis of this article, the general claim of Weber's philosophy of science is that there is no possibility of an ultimate rational, philosophical, or scientific grounding of values and normative theories. However, the social sciences are able to empirically study normative phenomena such as values and ideals. An empirical scientific discipline is e.g. capable of demonstrating which means and repercussions are inevitable for actions derived from "practical political evaluations (Wertungen)." ${ }^{51}$ In his article on "ethical neutrality" (Wertfreiheit), Weber discusses not only the social sciences, but philosophical disciplines such as ethics and their relation to value-judgments; "P h i l o s o p h i c a l disciplines can go further [than empirical ones] and lay bare the 'meaning' of 
evaluations, i.e., their ultimate $\mathrm{m}$ e a $\mathrm{n} \mathrm{i} \mathrm{n} \mathrm{g} \mathrm{f} \mathrm{u} \mathrm{l}$ structure and their meaningful consequences, in other words, they can indicate their 'place' within the totality of all the possible 'ultimate' evaluations and delimit their spheres of meaningful validity." 52 In general, through the "discussion of p r a c t i c a l v a l u e-j u d g e m e n ts" ( $p$ raktische Wertungen) one can achieve a clear understanding of them and answer several important questions: (a) What are "the ultimate, internally 'consistent' value-axioms"? ${ }^{53}$ (b) Which "implications" (Konsequenzen) for "practical evaluation of factual situations" are to be deduced from these ultimate value-axioms? (c) Which are the "factual consequences" and "undesired repercussions" if certain "practical evaluations" are realized through action? (d) Which "new axioms (and the postulates to be drawn from them)" can be uncovered ${ }^{54}$

Despite these possible achievements of a "discussion of $\mathrm{p} \mathrm{r} \mathrm{a} \mathrm{c} \mathrm{t}$ i c a l v a l u e-j u d g e m e n t s," Weber emphasizes the argumentative limits of both the social sciences and ethics in regard to a rational or scientific grounding of values. After mentioning the potential accomplishments of the "p h i l o s o p h i c a l disciplines," Weber makes a crucial statement that addresses once more his "decisionism,"

Even such simple questions as the extent to which an end should sanction unavoidable means, or the extent to which undesired repercussions [Nebenerfolge] should be taken into consideration, or how conflicts between several concretely conflicting ends are to be arbitrated [schlichten], are entirely matters of choice [Wahl] or compromise. There is no (rational or empirical) scientific procedure [Verfahren] of any kind whatsoever which can provide us with a decision [Entscheidung] here. The social sciences, which are strictly empirical sciences, are the least fitted to presume to save the individual the difficulty of making a choice, and they should therefore not create the impression that they can do so. ${ }^{55}$

52 Weber, "The Meaning of 'Ethical Neutrality'," 18; emphasis through letterspacing by Weber in the German original.

Dîvân

$2019 / 2$

53Weber does not give unequivocal examples of ultimate value-axioms. He might have in mind the ultimate values of nationalists, socialists, pacifists, or believers in a religion and their respective opposites; emphasis through letter-spacing by Weber in the German original.

54 Weber, "The Meaning of 'Ethical Neutrality'," 20-21.

55Weber, "The Meaning of 'Ethical Neutrality'," 18-19. 
The problem of the extent to which an end is able to "sanction unavoidable means" is a central question of Machiavelli's and Weber's thoughts on the relation of politics and ethics. In "The Profession and Vocation of Politics," Weber declares about this question that no "ethics in the world" is able to "determine when and to what extent the ethically good end 'sanctifies' the ethically dangerous means and side-effects." ${ }^{56}$ Weber's point about the limits of scientific reason could be illustrated by referring to recent debates on "humanitarian interventions." How should it be possible to ethically or scientifically determine whether a coalition of wellmeaning states would be justified to cause the death of 100,000 or even more innocent civilians to stop a genocide committed by an evil government through military strikes against its cities? Similar limits of reason come in sight when the question arises of how to scientifically determine which one of two or more conflicting ends or values is more desirable or worth choosing. How can one, e.g., scientifically decide the dispute between a localist, a nationalist, and a cosmopolitan about the questions of whether we all belong to a single community or which community morally deserves our primary political loyalty? In such a debate all three will be able to defend their views with reasons and arguments. And for practical purposes they could find or agree to a political compromise despite their opposed views. However, for good reasons Weber claims in a key phrase of his article on "ethical neutrality" (Wertfreiheit), "There is no (rational or empirical) scientific procedure of any kind whatsoever which can provide us with a decision here." This means that value conflicts cannot be definitely and conclusively argued out. For Weber, an ultimate rational grounding of values, norm or ideals is impossible.

In the context of his key phrase Weber does not indicate whether he criticizes specific rational or empirical scientific procedures that have been proposed to solve conflicts between values, norms, and ideals. It seems quite clear that it is impossible to solve a conflict between antagonistic values applying an empirical scientific procedure. However, in contemporary political philosophy, John Rawls proposed such a procedure to resolve conflicts between conceptions of justice. He claims that a democratic political culture contains "considered judgments" about justice such as "reli- 
gious intolerance and racial discrimination are unjust." ${ }^{57}$ According to Rawls's coherence theory, it is possible to extract both such "settled convictions" and "recognized basic ideas and principles" about justice from a "public political culture" and to seek to combine them "into a coherent conception of justice." ${ }^{58}$ However, the citizens of democratic political cultures display a plurality of antagonistic "considered judgments" about justice. There are liberals and libertarians, conservatives and socialists, and such like who disagree about conceptions of justice. Conflicts among values, norms, ideals, and "considered judgments" are part of one and the same political culture. Therefore, it is impossible to derive one "coherent conception of justice" from it.

In his Theory of Justice, Rawls proposes also a rational scientific procedure to decide between competing conceptions of justice. This is his "contractarian method," which derives principles of justice from a list of conceptions in an original position, integrating elements of "the theory of rational choice." ${ }^{59}$ However, Rawls later stated that it was a misleading error "to describe a theory of justice as part of the theory of rational choice." ${ }^{\prime 0}$ Nevertheless, in ethics

57 John Rawls, A Theory of Justice (Cambridge: Belknap Press of Harvard University Press, 1971), §§ 4, 9; 19, 46-53; John Rawls, "Justice as Fairness: Political not Metaphysical," Philosophy \& Public Affairs 14 (1984): 228.

58Rawls, "Justice as Fairness: Political not Metaphysical," 228; John Rawls, Political Liberalism Expanded edition (New York: Columbia University Press, 2005), 8.

59Rawls, A Theory of Justice, \$§ 3, 21; 16-17, 123-24.

60 Rawls, "Justice as Fairness: Political not Metaphysical," 237 (fn. 20). As early as 1980, Rawls reinterprets his theory of justice as fairness under the title "Kantian Constructivism in Moral Theory: The Dewey Lectures 1980," The Journal of Philosophy 77 (1980). According to Rawls's "Kantian Constructivism," the principles of justice are the outcome of a specific "procedure of construction," which is conducted by rational agents. In Political Liberalism, Rawls introduces the distinction between "moral and political constructivism" and defends, in line with narrowing down his theory to a "strictly political conception of justice," only the latter; Rawls, Political Liberalism, XV, 90 (fn. 1). In Political Liberalism, Rawls's "political constructivism" is linked to his method of "reflective equilibrium," which presupposes his "coherence theory"; Rawls, Political Liberalism, 8, 89, 95. In A Theory of Justice, the method of "reflective equilibrium" is linked to his "contractarian method" and "the theory of rational choice." For arguments that claim that Rawls's empirical and rational scientific procedures, which aim at resolving conflicts between conceptions of justice, are not successful and which explain why, see Manuel Knoll, "Deep Disagreements on Social and Political Justice: Their Meta-Ethical Relevance and $\bullet$ 
it is possible to conceive of rational procedures to solve a conflict between values, norms, and ideals. Take the conflict or disagreement between an ethical realist and cognitivist such as Plato and an anti-realist and moral skeptic. Plato claims both that an objective moral reality, primarily the form of the good, exists and that philosophers are able to achieve truth about it. If a philosopher who defended Plato's view, or a position similar to it, were able to both cogently demonstrate that such an objective moral reality exists and to successfully communicate his knowledge about it, he could refute the anti-realist who denies moral facts and the moral skeptic who rejects the possibility of moral truth. In this case, such a philosopher could solve value conflicts by pointing to his moral truths and use them as a standard to assess antagonistic values. In mainstream sciences, practitioners disagree with each other, say, about aspects of climate change, but there is some agreement on the methods and procedures how to settle or resolve such disagreements. However, "nothing remotely comparable" exists among moralists or moral philosophers. ${ }^{61}$ Until today, ethical realists keep quarreling with anti-realists, and cognitivists with moral skeptics.

In both ethics and political philosophy, justice is a central virtue or value. In his article on "ethical neutrality" (Wertfreiheit), Weber illustrates "the 'limits' of ethics" by referring to disagreements about social and political justice,

The implications of the postulate of 'justice' cannot be decided unambiguously by any ethic. Whether one, for example - as would correspond most closely with the views expressed by Schmoller - owes much to those who achieve much or whether one should demand much from those who accomplish much; whether one should, e. g., in the name of justice $[. .$.$] accord great opportunities to those with emi-$ nent talents or whether on the contrary (like Babeuf) one should attempt to equalize the injustice of the unequal distribution of mental capacities through the rigorous provision that talented persons, whose talent gives them prestige, must not utilize their better opportunities for their own benefit - these questions cannot be definitely answered

the Need for a New Research Perspective," New Perspectives on Distributive Justice. Deep Disagreements, Pluralism, and the Problem of Consensus, eds. Manuel Knoll, Stephen Snyder, and Nurdane Şimşek (Berlin / Boston: De Gruyter, 2019).

61 Jeremy Waldron, Law and Disagreement (Oxford: Oxford University Press, 1999), 178. 
[dürfte aus "ethischen Prämissen" unaustragbar sein]. The ethical problem in most social-political issues is, however, of this type." 62

In the literature, this passage has been discussed under the name of "Weber's 'Babeuf' antinomy." 63 However, in the dense and complex passage Weber shows that it is a distinctive feature of modernity that there exist not only irreconcilable conceptions of the good but of justice. ${ }^{64}$ Weber refers not only to Babeuf's view of distributive justice, but to several irreconcilable interpretations of "the postulate of 'justice'," e.g. the conflict of the performance principle with what Rawls calls the "principle of redress." ${ }^{65}$ Weber's main point is that the disagreement between these irreconcilable conceptions of justice "cannot be conclusively argued out based on "ethical premises' (dürfte aus "ethischen Prämissen" unaustragbar sein)." In the last phrase of the passage, Weber makes clear that such "limits' of ethics" apply most "social-political issues.” Though moral and political philosophers can give arguments, they cannot deliver an undisputable rational grounding for any of their different normative theories. There is no possibility of an ultimate rational, philosophical, or scientific grounding of values and normative theories. As already mentioned, Weber's position poses a serious challenge to both contemporary ethical theories and normative theories of justice. This is in particular true for neo-Kantians such as Rawls, who aim at an "overlapping consensus," or Habermas, who believes that unimpeded discourses and arguments based on communicative reason are generally able to lead to consensus in moral issues. Weber's criticism does not mean that practical philosophy is impossible but that it should have more modest aims. In 1978, Walter Gölz published his monograph on the problems of giving cogent reasons in practical philosophy. After reviewing all the relevant literature, he concludes that until today no one was able to refute Max Weber's theses on the limits of rational grounding. ${ }^{66}$

62 Weber, "The Meaning of 'Ethical Neutrality'," 15-16.

63 Turner and Factor, Max Weber and the Dispute over Reason and Value, 35.

64From Weber's perspective, Rawls's move to come to terms with the opposing conceptions of the good by striving for an agreement on a political conception of justice and a just social framework that allows these conception to coexist does not work.

65For an overview on these irreconcilable conceptions of social and political justice see Knoll, "Deep Disagreements on Social and Political Justice," 31 39.

66Walter Gölz, Begründungsprobleme der praktischen Philosophie (Stuttgart / Bad Cannstadt: Fromann-Holzboog, 1978), 12. Gölz agrees with the $*$ 


\section{THE RELATION OF POLITICS AND ETHICS AND WEBER'S DEFENSE OF AN ETHICS OF RESPONSIBILITY}

In “The Profession and Vocation of Politics," Weber distinguishes between two approaches to ethics that are opposed to each other. "Ethically oriented" human behavior can follow an "ethics of conviction" (Gesinnungsethik) or an "ethics of responsibility" (Verantwortungsethik). In more contemporary terms, this clash of approaches to ethics is a conflict between a deontological and a consequentialist ethics. ${ }^{67}$ Weber argues that only the latter, an ethics of responsibility, is appropriate for the sphere of politics. As already mentioned, his endorsement of an ethics of responsibility led to the criticism that Weber contradicts his postulate of "ethical neutrality (Wertfreiheit)." ${ }^{68}$ This section substantiates the third

second thesis of this article. According to Gölz, for Weber there is no possibility of "an exhaustive, i.e. complete and sufficient" rational grounding of statements about norms and values; Gölz, Begründungsprobleme der praktischen Philosophie, 14.

67 A deontological ethics claims that certain actions are always right or wrong in certain situations, no matter what the consequences are. For example, for a deontological ethics like Kant's lying or stealing are wrong actions in all situations; cf. C.D. Broad, Five Types of Ethical Theory (London: Kegan Paul, Trench, Trubner \& Co., Ltd., 1930), 206. A consequentialist ethics, on the contrary, holds that the judgment about the moral rightness or wrongness of an action depends exclusively on the quality of its foreseeable consequences. An action is right if, and only if, it has more good than bad consequences. Every consequentialist ethics contains a value theory that establishes which consequences of actions are desirable or valuable. Jeremy Bentham, the founder of both Utilitarianism and modern consequentialism, embraces only one value which he calls "utility." For him, utility is defined as the individual or common happiness or pleasure that is caused by an action. Utility is not a moral value. Today, a type of consequentialist ethics that makes the moral rightness or wrongness of an action exclusively dependent on its non-moral consequences is defined as a teleological ethics. While some decades ago it was common to oppose a "teleological" ethics to a deontological one, in contemporary ethics and its terminology a consequentialist ethics is opposed to a deontological ethics. The term "consequentialism" became established in the wake of G.E.M. Anscombe‘s article "Modern Moral Philosophy," which was published in 1958. The term was first coined in this paper; G.E.M. Anscombe, "Modern Moral Philosophy," Philosophy 33 / 124 (January 1958). Cf. Dieter Birnbacher, Analytische Einführung in die Ethik (Berlin / New York: De Gruyter, 2003), 113-14. 
thesis of this article, according to which Weber's endorsement is compatible with his postulate. ${ }^{69}$

The understanding of politics, on which Weber's "The Profession and Vocation of Politics" is based, is a realist one. According to a political realist, politics is about power, struggle, and conflict. The pinnacle of Weber's 1919 talk are his astute considerations on the relation of politics and ethics. Weber refuses both the interpretation that they have "nothing at all to do with one another" and the view "that political action is subject to 'the same' ethics as every other form of activity." ${ }^{70}$ His rejection of the latter interpretation starts off with the insight that human actions belong to heterogeneous spheres and that it is therefore very difficult to ethically regulate them in a coherent way:

But is it in fact true that any ethics in the world could establish substantially identical commandments [inhaltlich gleichen Gebote] applicable to all relationships, whether erotic, business, family or official, to one's relations with one's wife, greengrocer, son, competitor, with a friend or an accused man? Can the fact that politics operates with a quite specific means, namely power, backed up by the use of violence [Gewaltsamkeit], really be a matter of such indifference as far as the ethical demands placed on politics are concerned $?^{71}$

The use of violence is not only the "specific means," but also the "decisive means" of politics. For Weber, the tasks of politics "can only be achieved by force [Gewalt]."72 Despite his conception of politics, Weber rejects the view that politics and ethics have noth-

69 Bruun criticizes historians, political scientists, and sociologists that they usually discuss Weber's political views on power and conflict "in relative isolation from his theory of scientific inquiry"; Bruun, Science, Values and Politics, 239.

70Weber, "The Profession and Vocation of Politics," 357; cf. 357-68. Weber does not explain who are the protagonists of these two interpretations. The view that all forms of human activity are "subject to 'the same' ethics" might be derived from the view of the three main monotheistic religions, according to which God gave Moses his ten commandments, of which six express univocal ethical demands (Do not kill, etc.).

71 Weber, "The Profession and Vocation of Politics," 357.

72Weber, "The Profession and Vocation of Politics," 360, 366. Weber's close association of political and military power has been criticized. Michael Mann argues, "True, the state uses force, but only as means to back up its rules, which are given no particular content”; Michael Mann, The Sources of Social Power, Vol. II: The rise of classes and nation-states, 1760-1914 (Cambridge: Cambridge University Press, 1993), 55. 
ing to do with each other. Rather, the unavoidable violence of political practice is the reason for political ethics: "The specific means of legitimate violence per se in the hands of human associations is what gives all the ethical problems of politics their particular character."73

Weber's realist conception of politics is crucial for understanding his thought on the relation of politics to ethics. Weber distinguishes between two approaches to ethics that are opposed to each other,

That is the crucial point. We have to understand that ethically oriented activity can follow two fundamentally different, irreconcilably opposed maxims [unaustragbar gegensätzlichen Maximen]. It can follow the 'ethics of principled conviction' (Gesinnung) or the 'ethics of responsibility'. It is not that the ethics of conviction is identical with irresponsibility, nor that the ethic of responsibility means the absence of principled conviction - there is of course no question of that. But there is a profound opposition [abgrundtiefer Gegensatz] between acting by the maxim of the ethics of conviction (putting it in religious terms: 'The Christian does what is right and places the outcome in God's hands'), and acting by the maxim of the ethic of responsibility which means that one must answer for the (foreseeable) consequences of one's actions. ${ }^{74}$

Weber illustrates the ethics of conviction with the Christian "ethics of the Sermon on the Mount" that he understands as an "absolute ethics" that asks its followers to "turn the other cheek." 75

73Weber, "The Profession and Vocation of Politics," 364.

74Weber, "The Profession and Vocation of Politics," 359; cf. Weber, "The Meaning of 'Ethical Neutrality'," 16.

75Weber, "The Profession and Vocation of Politics," 357. Bruun points out that there are three "variants of action motivated by an ethic of conviction": "the religious-acosmistic, the pacifist-political, and the radical-revolutionary attitude"; Bruun, Science, Values and Politics in Max Weber's Methodology, 251. The term "ethics of conviction" was first used by Wilhelm Windelband in his "Geschichte der Philosophie" published in 1892. Windelband uses the term in the context of his presentation of Abelard's and Kant's ethics. In his Hauptprobleme der Ethik, published 1903, Paul Hensel uses the contrast of a "Gesinnungsethik" with a "Erfolgsethik." As a representative of the latter he refers to Bentham's Utilitarianism. Cf. Manuel Knoll, "Max Webers Machiavelli-Rezeption. Die Konsequenzen des politischen Realismus für das Verhältnis von Ethik und Politik, " Der Machtstaat. Niccolò Machiavelli als Theoretiker der Macht im Spiegel der Zeit, eds. Volker Reinhardt, Rüdiger Voigt, and Stefano Saracino (BadenBaden: Nomos, 2015), 254. 
The ethics of conviction is not concerned about the consequences of actions. In the terminology of contemporary ethics, the ethics of conviction corresponds to a deontological ethics. The ethics of conviction is radically opposed to the ethics of responsibility. Someone who subscribes to the ethics of responsibility has a realistic view of the shortcomings of human beings. Such a person "does not feel that he can shuffle off the consequences of his own actions, as far as he could foresee them, and place the burden on the shoulders of others. He will say, 'These consequences are to be attributed to my actions.'."76 A person who is oriented by an ethic of responsibility acknowledges his responsibility for the consequences of his actions. In the terminology of contemporary ethics, the ethics of responsibility corresponds to a consequentialist ethics.

Weber both denies that "the ethics of conviction is identical with irresponsibility" and claims that the ethics of responsibility does not mean "the absence of principled conviction." The first means that a person who follows an ethics of conviction feels responsible for the purity of her intentions, "inner" principles, and values. The second indicates that a person who is oriented by an ethics of responsibility also has certain convictions, goals, and values. Weber even refers to exceptional situations, in which the ethics of responsibility and the ethics of conviction are not "absolute opposites" but "complementary to each other [Ergänzungen]." ${ }^{77}$ Despite these

76Weber, "The Profession and Vocation of Politics," 360. The term "ethics of responsibility" was coined by Max Weber. He associates it with what already before him was called "Realpolitik" (as opposed to "Idealpolitik"). Weber transformed the term "ethics of success" (Erfolgsethik), which was current at his time, into the term "Verantwortungsethik"; cf. Knoll, "Max Webers Machiavelli-Rezeption," 254. In 1906, Weber himself uses the term "Erfolgsethik," which in the English translation is rendered erroneously with "ethics of 'consequentialism'; Weber, "On the Situation of Constitutional Democracy in Russia," in Weber. Political Writings, 42.

77 Weber, "The Profession and Vocation of Politics," 368. Such an exceptional situation arises when someone, "who acts on the basis of an ethics of responsibility, says at some point, 'Here I stand, I can do no other'”; Weber, "The Profession and Vocation of Politics," 367. In this context, Bruuns claims that Weber distinguishes between "two ethics of conviction" and views one type, which he calls the "responsible ethic of conviction," as the true "ethic of politics"; Bruun, Science, Values and Politics in Max Weber's Methodology, 272; cf. 49. The problem of Bruun's interpretation is that it fails to recognize that the so-called second type is just the expression of a very rare clash of the two approaches to ethics within one person that might occur only in exceptional situations. When Weber introduces the $\bullet$ 
commonalities, Weber clearly states that on the essential level "there is a profound opposition" between the opposing maxims that correspond to these two kinds of "ethically oriented activity" and that this opposition cannot be "conclusively argued out" (unaustragbar gegensätzlichen Maximen). This means that there is no ethical or scientific authority and no rational or empirical scientific procedure that could provide and ultimate and undisputable solution for the clash of these two approaches to ethics. Every leading politician has to rely on her own judgment and needs "to choose" between one of the two approaches and their corresponding "ultimate Weltanschauungen."78

There is a high likelihood that Weber's considerations on the relations of politics and ethics are inspired by his study of Machiavelli's writings. In the context of these short considerations, he mentions Machiavelli and his works several times. ${ }^{79}$ In these mentions, Weber also makes it plain that he does not share the widespread criticism of the Florentine. Most important, in his considerations Weber focuses on the main problems of Machiavelli's political ethics. ${ }^{80}$ These concern the tension between traditional morality and politics and the relation between bad means and good ends. A central question for a realist conception of politics, which Weber and Machiavelli share, is the relation of means and ends and in particular the question of the extent to which a good end is able to sanction immoral means. Both are convinced that it is possible

topics of the "ethos of politics as a 'cause' [Sache]" and the "ethical home of politics," he clearly states: "At this point, admittedly, ultimate Weltanschauungen collide, and one has eventually to choose between them";Weber, "The Profession and Vocation of Politics," 355.

78Weber, "The Profession and Vocation of Politics," 355. In all likelihood, the lack of an ethical authority or scientific procedure to "conclusively argue out" the conflict between the opposed approaches to ethics explains Weber's statement that has been taken to be "confusing": "But whether one ought to act on the basis of an ethics of conviction or one of responsibility, and when one should do the one or the other, these are not things about which one can give instructions to anybody"; Weber, "The Profession and Vocation of Politics,” 367; Bruun, Science, Values and Politics, 271.

79Weber, "The Profession and Vocation of Politics," 360, 363, 366. In the biography of her husband, Marianne Weber reports that when he was only 12 years old Weber told his mother that he borrowed Machiavelli's Prince and intended to read the Anti-Machiavel next; Marianna Weber, Max Weber. Ein Lebensbild (München / Zürich: Pieper, 1989), 48.

80Cf. M. Knoll, “Machiavelli's Consequentialist Ethics of Responsibility," History of Political Thought 40 (2019/4).

Dîvân

133 
to achieve knowledge about the means necessary to achieve given political ends and to rationally calculate their usage.$^{81}$ Concerning the tension between morality and politics and the relation between bad means and good ends Weber explains,

No ethics in the world can get round the fact that the achievement of 'good' ends is in many cases tied to the necessity of employing morally suspect or at least morally dangerous means, and that one must reckon with the possibility or even likelihood of evil side-effects. Nor can any ethics in the world determine when and to what extent the ethically good end 'sanctifies' the ethically dangerous means and side-effects. ${ }^{82}$

Weber indicates his preference for an ethics of responsibility by merely asking "when and to what extent" a good end can justify an immoral means instead of questioning whether this is possible at all. For him, the former question is among the "ethical paradoxes" that no ethics can decide. ${ }^{83}$ Therefore, in such a difficult situation every leading politician has to make her individual decision and is morally responsible for its consequences. Weber's preference for an ethics of responsibility can be seen also from the fact that he includes "sense for responsibility" (Verantwortungsgefühl) as one of the three main qualities that a politician needs to have. ${ }^{84}$ The other two qualities are "passion" (Leidenschaft) and "judgment" (Augen$m a ß)$. Weber even regards the "feeling of responsibility" to be the most important quality as it includes the other two. The passion of a politician should be a "passionate commitment to a 'cause' [Sache]," for which she feels responsible. ${ }^{85}$

81 According to Machiavelli, there is a certain "necessity" (necessità) in history that allows us to compare political events and to learn from them. This necessity is mainly rooted in human nature, which has been the same in antiquity as it is today. For Weber, the social sciences are able to determine which means are necessary to realize ends or values through political action. In a political community, it is in particular the bureaucracy that possess the "technical" knowledge about the means necessary to reach desired results. Despite their conviction of such possible achievements of scientific reason, both share the insight that we are living in a contingent world and that there are severe limits to predicting the effects and consequences of political actions or plans. "mere "power-politician'” who strives for power for its own sake. Power is the indispensible means of politics but it should always serve a "cause" $\bullet$ 
According to Weber, Christian ethics or an ethics of conviction is not appropriate for the sphere of politics. The main reason for this is that for such kind of ethics it is prohibited to employ violence, the specific means of politics,

It seems that the ethics of conviction is bound to founder hopelessly on this problem of how the end is to sanctify the means. Indeed the only position it can logically take is to reject any action which employs morally dangerous means. Indeed the only position it can logically take is to reject any action which employs morally dangerous means. ${ }^{86}$

This is the main argument with which Weber rejects the ethics of conviction for the sphere of politics. He also criticizes it by saying that an ethics that asks to turn the other cheek is "an ethic of indignity, except for a saint." ${ }^{87}$ For Weber, the only appropriate ethics for the sphere of politics is an ethics of responsibility according to which a leading politician is morally responsible for the consequences of her decisions. All "Realpolitik" has its "point of departure" in the postulate that "the responsibility for the predictable consequences of the action is to be taken into consideration." ${ }^{88}$ However, for a politician with real decision-making power it is impossible to foresee all consequences, effects, and side-effects of a decision. An ethics of responsibility is not able to spare her from making difficult and troubling decisions and cannot "issue an ethical decree determining which end shall sanctify which means." ${ }^{89}$ Therefore, every politician has to decide for herself and shoulder the moral responsibility of her decisions. In politics, "diabolic powers" are at work and a leading politician will in all likelihood be entangled in guilt and will endanger the "salvation of his soul."90

In his Habilitationsschrift, Lothar Waas claims that Weber contradicts himself by, on the one hand, claiming that the clash between the two types of ethics cannot be "argued out" (ausgetragen)

(Sache). However, "The nature of the cause the politician seeks to serve by striving for and using power is a question of faith"; Weber, "The Profession and Vocation of Politics," 354-55. A leading politician needs to decide about her cause and her goals.

86Weber, "The Profession and Vocation of Politics," 361.

87 Weber, "The Profession and Vocation of Politics," 358.

88 Weber, "The Meaning of 'Ethical Neutrality', " 16.

89Weber, "The Profession and Vocation of Politics," 362.

90Weber, "The Profession and Vocation of Politics," 366. 
and, on the other, endorsing an ethics of responsibility. ${ }^{91}$ However, Weber's point is not that one cannot argue about this conflict, but that it cannot be conclusively argued out by scientific or ethical reason. This means that there cannot be a scientific ultimate rational grounding for either approach to ethics. No ethicist or social scientist is able to scientifically decide for the politician what to do and how to act. Nevertheless, as Weber's discourse on politics clearly demonstrates, it is possible to argue both that an ethics of responsibility is appropriate for the sphere of politics and that an ethics of conviction is not. The crucial point here is that Weber does not claim that his arguments for an ethics of responsibility provides an absolute or ultimate rational grounding for it. He formulates his arguments not as a social scientist or as an ethicist, but as a political publicist. ${ }^{92}$ Therefore, Waas's claim that Weber contradicts himself cannot be upheld.

\section{BIBLIOGRAPHY}

Anscombe, G.E.M. "Modern Moral Philosophy.” Philosophy 33 / 124 (January 1958): 1-19.

Berg-Schlosser, Dirk, and Theo Stammen. Einführung in die Politikwissenschaft. München: Beck, 1995.

Berlin, Isaiah. "The Originality of Machiavelli" (first published 1972). Isaiah Berlin, Against the Current. Essays in the History of Ideas, ed. Henry Hardy. 2nd. edition, 33-100. Princeton: Princeton University Press, 2013 (original 1979).

Bienfait, Agathe. Freiheit, Verantwortung, Solidarität. Zur Rekonstruktion des politischen Liberalismus. Frankfurt am Main: Suhrkamp, 1999.

91 Waas, Max Weber und die Folgen, 22.

92 Weber's "role as publicist, as a politically - above all nationally - committed scholar" and as "an active and aggressive public figure" has often been emphasized; Bruun, Science, Values and Politics in Max Weber's Methodology, 259; Turner, and Factor, Max Weber and the Dispute over Reason and Value: A Study in Philosophy, Ethics, and Politics, 15. Bruun criticizes that in his talk on politics Weber "oscillates between the level of scientific discourse and the level of personal (political or ethical) commitment. The methodologically relevant passages in it are often formulated in personal terms, as subjective ethical judgments"; Bruun, Science, Values and Politics in Max Weber's Methodology, 259. 
Birnbacher, Dieter. Analytische Einführung in die Ethik. Berlin / New York: De Gruyter, 2003.

Broad, C.D. Five Types of Ethical Theory. London: Kegan Paul, Trench, Trubner \& Co., Ltd., 1930.

Bruun, Hans Henrik. Science, Values and Politics in Max Weber's Methodology. New Expanded Edition. Aldershot: Ashgate, 2007.

Frankel, Benjamin, ed. The Roots of Realism. London/Portland: Routledge, 1996.

Gerner, Andrea. Wissenschaft und Leben. Max Webers Antwort auf eine Frage Friedrich Nietzsches. Göttingen: Vandenhoeck \& Ruprecht, 1994.

Gölz, Walter. Begründungsprobleme der praktischen Philosophie. Stuttgart/ Bad Cannstadt: Fromann-Holzboog, 1978.

Hennis, Wilhelm. "Die Spuren Nietzsches im Werk Max Webers." Max Webers Fragestellung. Studien zur Biographie des Werkes, ed. Wilhelm Hennis, 167-91. Tübingen: Mohr / Siebeck, 1987.

Knoll, Manuel. "Nietzsches Kritik am Willen zum Wissen und die intellektuelle Tugend der Redlichkeit." Nietzsches Wissenschaftsphilosophie. Hintergründe, Wirkungen und Aktualität, eds. Günther Abel, Marco Brusotti, and Helmut Heit, 257-70. Berlin/Boston: De Gruyter, 2012.

“Max Webers Machiavelli-Rezeption. Die Konsequenzen des politischen Realismus für das Verhältnis von Ethik und Politik." Der Machtstaat. Niccolò Machiavelli als Theoretiker der Macht im Spiegel der Zeit, eds. Volker Reinhardt, Rüdiger Voigt, and Stefano Saracino, 241-67. BadenBaden: Nomos, 2015.

"Deep Disagreements on Social and Political Justice: Their Meta-Ethical Relevance and the Need for a New Research Perspective." New Perspectives on Distributive Justice. Deep Disagreements, Pluralism, and the Problem of Consensus, ed. Manuel Knoll, Stephen Snyder, and Nurdane Şimşek, 23-51. Berlin/Boston: De Gruyter, 2019.

_ "Machiavelli's Consequentialist Ethics of Responsibility." History of Political Thought 40 (2019/4): 631-48.

Mann, Michael. The Sources of Social Power, Vol. II: The rise of classes and nation-states, 1760-1914. Cambridge: Cambridge University Press, 1993.

Nietzsche, Friedrich. Beyond Good and Evil. Trans. W. Kaufmann. New York: Vintage Books, 1989 (original 1966).

The Gay Science. Trans. J. Nauckhoff. Cambridge: Cambridge University Press, 2001.

- On the Genealogy of Morality. Trans. C. Diethe. Cambridge: Cambridge University Press, 1997. 
— Thus Spoke Zarathustra. Trans. A. del Caro. Cambridge: Cambridge University Press, 2006.

— "Twighlight of the Idols." Friedrich Nietzsche, The Antichrist, Ecce Homo, Twighlight of the Idols, and other Writing. Trans. J. Norman. Cambridge: Cambridge University Press, 2005.

Palonen, Kari. Eine Lobrede für Politik. Ein Kommentar zu Max Webers "Politik als Beruf." Opladen: Leske \& Buderich, 2002.

Peukert, Detlev. Max Webers Diagnose der Moderne. Göttingen: Vandenhoeck \& Ruprecht, 1989.

Radbruch, Gustav. “Anglo-American Jurisprudence Through Continental Eyes.” Law Quarterly Review 208 (1936): 530-45.

Radbruch, Gustav. Einführung in die Rechtswissenschaft. 2nd. Edition. Leipzig: Quelle \& Meyer, 1913 (original 1910).

Rawls, John. A Theory of Justice. Cambridge: Belknap Press of Harvard University Press, 1971.

_ "Kantian Constructivism in Moral Theory: The Dewey Lectures 1980," The Journal of Philosophy 77 (1980): 515-72.

__ "Justice as Fairness: Political not Metaphysical." Philosophy \& Public Affairs 14 (1984): 223-51.

_ Political Liberalism. Expanded edition. New York: Columbia University Press, 2005.

Schluchter, Wolfgang. Religion und Lebensführung, Bd. 1: Studien zu Max Webers Kultur- und Werttheorie. Frankfurt am Main: Suhrkamp, 1988.

Schwaabe, Christian, Freiheit und Vernunft in der unversöhnten Moderne. Max Webers kritischer Dezisionismus als Herausforderung des politischen Liberalismus. München: Fink, 2002.

Schwaabe, Christian. "Das Schicksal des Menschen im Schatten des toten Gottes. Zur Bedeutung Friedrich Nietzsches für Max Webers Diagnose der Moderne." Der Wille zur Macht und die "große Politik" - Friedrich Nietzsches Staatsverständnis, ed. Hans-Martin Schönherr-Mann, 23557. Baden Baden: Nomos, 2010.

Shaw, Tamsin. “The 'Last Man' Problem: Nietzsche and Weber on Political Attitudes to Suffering." Nietzsche as Political Philosopher, ed. Manuel Knoll and Barry Stocker, 345-80. Berlin/Boston: De Gruyter, 2014.

Turner, Stephen P., and Factor, Regis A. Max Weber and the Dispute over Reason and Value: A Study in Philosophy, Ethics, and Politics. London:

Dîvân

$2019 / 2$ Routledge, 1984.

Waldron, Jeremy. Law and Disagreement. Oxford: Oxford University Press, 1999. 
Waas, Lothar. Max Weber und die Folgen. Die Krise der Moderne und der moralisch-politische Dualismus des 20. Jahrhunderts. Frankfurt am Main / New York: Campus, 1995.

Weber, Marianna. Max Weber. Ein Lebensbild. München/Zürich: Pieper, 1989 (original 1926).

Weber, Max. "The Meaning of 'Ethical Neutrality' in Sociology and Economics." Max Weber, The Methodology of the Social Sciences, trans. and eds. Edward Shills and Henry Finch, 1-47. Illinois: The Free Press of Glencoe, 1949.

“'Objectivity' in Social Science and Social Policy." Max Weber, The Methodology of the Social Sciences, trans. and eds. by Edward Shills and Henry Finch, 50-112. Illinois: The Free Press of Glencoe, 1949.

_ Gesammelte Politische Schriften, ed. Johannes Winckelmann. UTB für Wissenschaft, and Uni-Taschenbücher 1491; Tübingen: J.C.B. Mohr / PaulSiebeck, 1988, 5th ed.

_ "Parliament and Government in Germany under a New Political Order.” Weber. Political Writings, eds. Peter Lassmann and Ronald Speirs, 130-271. Cambridge: Cambridge University Press, 1994.

_ "The Profession and Vocation of Politics." Weber. Political Writings, eds. Peter Lassmann and Ronald Speirs, 309-69. Cambridge: Cambridge University Press, 1994.

"Science as Vocation." From Max Weber. Essays in Sociology, trans. and eds. H.H. Gerth and C. Wright Mills, 129-56. Oxford: Oxford University Press, 1946.

_ “On the Situation of Constitutional Democracy in Russia." Weber. Political Writings, eds. Peter Lassmann and Ronald Speirs, 29-74. Cambridge: Cambridge University Press, 1994.

_ “The Social Psychology of the World Religions." From Max Weber. Essays in Sociology, trans. and eds. H.H. Gerth and C. Wright Mills, 267301. Oxford: Oxford University Press, 1946.

Westphal, Kenneth R. "Cosmopolitanism without Commensurability: Why Incommensurable Values are Worthless.” Jahrbuch für Recht und Ethik 27 (2019): 243-66; Gedächtnisschrift für Joachim Hruschka (†10.12.2017). 


\section{MAX WEBER'İN SIYYASET, AKIL, DEĞERLERİN ÇATIŞMASI VE ETIKK ÜZERİNE DÜŞÜNCELERİ}

\section{ÖZ}

Bu makale, Max Weber'in değer çatışması teorisinin realist politika anlayışıyla bağlantısını ve politikayla etik arasındaki ilişkiyi nasıl tasavvur ettiğini incelemektedir. Bu inceleme, aynı zamanda Weber'in sosyal bilimler ve etik alanında aklın sınırı hakkındaki görüşlerini de kapsamaktadır. Weber'in bilim felsefesinin merkezi, sosyal bilimlerin "etik tarafsızlı̆̆ı" (Wertfreiheit) hakkındaki metodolojik düşünceleridir. Bu makalenin ilk tezi, Weber'in uzlaşmaz değerler ve idealler çatışması teorisinin Nietzsche'ye dayandığını ileri sürmektedir. Makalenin ikinci tezine göre, Weber'in bilim felsefesinin genel iddiası değerlerin ve normatif teorilerin nihai rasyonel, felsefi veya bilimsel bir temelinin bulunma ihtimalinin olmadığıdır. Weber'in politik alandaki sorumluluk etiğine destek vermesi, bilim adamının "etik tarafsızlığı" (Wertfreiheit) varsayımına aykırı olduğu eleştirisine yol açmaktadır. Makalenin üçüncü tezi, Weber'in politik sorumluluk etiği konusundaki savlarının metodolojik postülasıyla uyumlu olduğunu iddia etmektedir.

Anahtar Kelimeler: Max Weber, Siyaset, Akıl, Ahlak, Değerler çatışması, Siyasi realizm, Ahlaki Tarafsızlık. 